\title{
Strawberry Runner Production Enhanced by Plant Growth Promoting Rhizobacteria
}

\author{
Anuradha $^{1 *}$, R.K. Goyal ${ }^{1}$, A.K. Godara ${ }^{1}$ and S.S. Sindhu ${ }^{2}$ \\ ${ }^{1}$ Department of Horticulture, ${ }^{2}$ Department of Microbiology, CCS Haryana Agricultural \\ University, Hisar, Haryana - 125001, India \\ *Corresponding author
}

\section{A B S T R A C T}

\section{Keywords}

Strawberry, Pseudomonas strains, Runners

Article Info

Accepted:

26 October 2018

Available Online:

10 November 2018
The present experiment was conducted at Hi-tech greenhouse of Precision farming development center of the Department of Horticulture, CCS Haryana Agricultural University, Hisar (Haryana) during the year 2016-17 and 2017-18.Strawberry plants were inoculated with different strains of Pseudomonas and plants inoculated with Pseudomonas strains fertilized with $75 \%$ RDF. It was observed that maximum number of runner per plant was recorded in plants fertilized with $100 \%$ RDF, however number of runner per plant increased with the application of rhizobacterial strains as compared to control, i.e., $75 \%$ RDF. The highest number of runners per plant was obtained from the plants fertilized with treatment $\mathrm{PS}_{0}: 100 \% \mathrm{RDF}$ (5.80 and 7.50), followed by the treatment $\mathrm{PS}_{10}: 75 \% \mathrm{RDF}$ + CP109 (4.25 and 7.00), while the minimum number of runners per plant was recorded under the control treatment $\mathrm{PS}_{0}$ : $75 \%$ RDF (3.00 and 4.25) during the year 2016-17 and 2017-18, respectively.

\section{Introduction}

Strawberry (Fragaria $\times$ ananassa Duch.) belonging to the family Rosaceae is known as one of the most attractive, delicious and refreshing fruits of the world and occupies an important place among the orchard plants. Strawberry can be successfully grown in plains as well as in hills up to an elevation of 3000 meters above mean sea level in humid or dry regions. In India, the cultivated area under strawberry mainly located in Maharashtra, Himachal Pradesh, Uttar Pradesh, Haryana and the Nilgiri hills is nearly 1,000 ha with a production of 5,000 tonne, and in Haryana, it is around 150 ha with a production of 2,010 tonne. Hisar and Bhiwani districts of Haryana have emerged as a hub of strawberry in Northern India and the second largest producer of exotic fruit after Mahabaleshwar in Maharashtra (Rao and Saxena, 2017). In this area, strawberry cultivation is picking up fast due to availability of its market in Delhi and its quick considerable income and nutritional values.

The continuous increases in its cultivation acreage should be concomitant with the 
development of new production practice (Anuradha et al., 2013). Strawberry is conventionally propagated by runners. Although propagation by runners retains all the characters of the parent but viral diseases are also transmitted through runners especially when parent material is infected. Biofertilizers, more appropriately called microbial inoculants, are the preparations containing live or latent cells of efficient strains of microorganisms. These biofertilizers are a cost effective renewable energy source and play a crucial role in reducing the inorganic fertilizer application and at the same time increasing the quality and yield of flowers besides maintaining soil fertility.

Some of the plant bio-regulators are synthesized endogenously but occasionally needed to be supplemented exogenously for additional stimulus in short duration crops like strawberry that require quick response for increased the runner production. The formation of healthy runners and higher rates of multiplication is one of the pre-requisite of an economically viable propagation. Keeping this in view, the present investigation was undertaken with the objective: Inoculation response of Pseudomonas strains on runner production of strawberry.

\section{Materials and Methods}

The experiment was conducted at $\mathrm{Hi}$-tech greenhouse of Precision farming development centre of the Department of Horticulture, CCS Haryana Agricultural University, Hisar (Haryana) situated at $215.2 \mathrm{~m}$ above sea level with co-ordinates of $29^{\circ} 10^{\prime} \mathrm{N}$ latitude and $75^{\circ}$ 46' E longitudes during the year 2016-17 and 2017-18. The strawberry cultivar Chandler was chosen for experiment with eleven treatments and four replications. Pseudomonas strains were procured from the Department of Microbiology Biocontrol lab. Eleven treatments $\mathrm{PS}_{0}$ to $\mathrm{PS}_{10}$ and $\mathrm{PS}_{0} 100 \% \mathrm{RDF}$ and other treatments plants inoculated with Pseudomonas strains fertilized with $75 \%$ RDF. $5 \mathrm{ml}$ of each strain was taken and inoculated each plants near to root pheriphery region of plants after the transplanting of strawberry plants when their root established properly.

\section{Results and Discussion}

The data pertaining to number of runners per plant have been presented in Table 1. Different strains of Pseudomonas with $75 \%$ RDF significantly affected the number of runners per plant in strawberry.

Table.1 Effect of Pseudomonas strains on number of runners per plant in strawberry

\begin{tabular}{|c|}
\hline Treatments \\
\hline $\mathrm{PS}_{0}: 100 \% \mathrm{RDF}$ \\
\hline $\mathrm{PS}_{1}: 75 \%$ RDF (control) \\
\hline $\mathrm{PS}_{2}: 75 \%$ RDF + HMM65 (Pseudomonas control) \\
\hline $\mathrm{PS}_{3}:$ 75\% RDF + HMM92 \\
\hline $\mathrm{PS}_{4}: \mathbf{7 5 \%}$ RDF + JMM15 \\
\hline $\mathrm{PS}_{5}: \mathbf{7 5} \%$ RDF + JMM19 \\
\hline $\mathrm{PS}_{6}: 75 \%$ RDF + HMM57 \\
\hline $\mathrm{PS}_{7}: \mathbf{7 5 \%}$ RDF + WHA87 \\
\hline $\mathrm{PS}_{8}: \mathbf{7 5 \%} \mathrm{RDF}+\mathrm{CPS67}$ \\
\hline $\mathrm{PS}_{9}: \mathbf{7 5 \%}$ RDF + MHA75 \\
\hline $\mathrm{PS}_{10}: 75 \% \mathrm{RDF}+\mathrm{CP} 109$ \\
\hline CD at $5 \%$ level of significance \\
\hline
\end{tabular}

\begin{tabular}{|c|c|c|}
\hline $\mathbf{2 0 1 6 - 1 7}$ & $\mathbf{2 0 1 7 - 1 8}$ & Pooled mean \\
\hline 5.80 & 7.50 & 6.65 \\
\hline 3.00 & 4.25 & 3.63 \\
\hline 3.00 & 4.25 & 3.63 \\
\hline 3.25 & 4.50 & 3.88 \\
\hline 3.50 & 4.25 & 3.88 \\
\hline 3.50 & 5.00 & 4.25 \\
\hline 4.00 & 5.50 & 4.75 \\
\hline 3.75 & 6.00 & 4.88 \\
\hline 4.00 & 6.50 & 5.25 \\
\hline 4.25 & 6.75 & 5.50 \\
\hline 4.25 & 7.00 & 5.63 \\
\hline $\mathbf{0 . 2 3}$ & $\mathbf{0 . 2 8}$ & $\mathbf{0 . 2 4}$ \\
\hline
\end{tabular}


The highest number of runners per plant was obtained from the plants fertilized with treatment $\mathrm{PS}_{0}: 100 \% \operatorname{RDF}$ (5.80 and 7.50), followed by the treatment $\mathrm{PS}_{10}$ : $75 \% \mathrm{RDF}+$ CP109 (4.25 and 7.00), while the minimum number of runners per plant was recorded under the control treatment $\mathrm{PS}_{0}: 75 \% \mathrm{RDF}$ (3.00 and 4.25) during the year 2016-17 and 2017-18, respectively.

The present results are in line with the findings of Tripathi et al., (2015) who reported that increased number of runner per plant might be due to increased growth of plant, which accumulated more photosynthates, therefore, increased the number of runners per plant in strawberry and similar results were reported by Pirlak and Kose (2009) and Gupta and Tripathi (2012).

\section{References}

Anuradha (2015) In vitro propagation and genetic fidelity studies in strawberry.
M.Sc. thesis. CCS Haryana Agricultureal University.

Gupta, A. K. and Tripathi, V. K. (2012) Efficacy of Azotobacter and vermicompost alone and in combination on vegetative growth, flowering and yield of strawberry (Fragariax ananassa Duch.) cv. Chandler. Progressive Horticulture, 44 (2), 256261.

Pirlak Lutfi and Kose Murat. (2009) Effects of plant growth promoting rhizobacteria on yield and some fruit properties of strawberry. Journal of Plant Nutrition, 32(7), 1173- 1184.

Rao, S.P., and M. Saxena (2017) Horticulture statitics at Glance. Ministry of Agriculture and Farmer Welfare, Government of India.

Tripathi, V.K., Kumar, S. and Gupta, A.K. (2015) Influence of Azotobacter and vermicompost on growth, flowering, yield and quality of strawberry cv. Chandler. Indian Journal of Horticulture, 72(2), 201-205.

\section{How to cite this article:}

Anuradha, R.K. Goyal, A.K. Godara and Sindhu, S.S. 2018. Strawberry Runner Production Enhanced by Plant Growth Promoting Rhizobacteria. Int.J.Curr.Microbiol.App.Sci. 7(11): 3236-3238. doi: https://doi.org/10.20546/ijcmas.2018.711.372 